Volume $4 \cdot$ Nomor 3. • Juni 2021

Pege (Hal.) : $368-379$

(C) Universitas Pamulang

JL.Surya Kencana No.1 Pamulang, Tangerang Selatan - Banten

Telp. (021) 7412566, Fax (021) 7412491

website. :

Email : jurnalmarketing.unpam@gmail.com

\title{
Pengaruh Store Atmosphere dan Kualitas Produk Terhadap Kepuasan Pelanggan (Survey Pada Café Patroli Kopi Karawang)
}

\author{
Febby Febriani ${ }^{1}$; Dadan Ahmad Fadili ${ }^{2}$ \\ Universitas Singaperbangsa Karawang, febbyfozaw@gmail.com; dadan.ahmad@fe.unsika.ac.id
}

\begin{abstract}
Abstrak. Penelitian ini dimaksudkan untuk menguji serta menganalisis tentang Pengaruh Store Atmosphere dan Kualitas Produk Terhadap Kepuasan Pelanggan Café Patroli Kopi. Penelitian dilakukan dengan menggunakan metode kuantitatif dengan analisis verifikatif yakni mengumpulkan, mengemukakan, menganalisis, dan melakukan pengujian hipotesis, dan membuat kesimpulan. Sampel pada penelitian ini berjumlah 265 dengan menggunakan teknik Non Probability Sampling dengan metode Sampel Insidental. Teknik analisis data yang digunakan yaitu teknik analisis kualitas data yaitu uji validitas dan reliabilitas, uji normalitas, analisis korelasi, analisis jalur, koefisien determinasi, dan uji hipotesis. Berdasarkan analisis yang telah dilakukan, koefisien korelasi antara variabel store atmosphere dengan kualitas produk diperoleh nilai sebesar 0,744 yang berarti mempunyai tingkat korelasi yang kuat, positif dan signifikan. Pengaruh secara parsial kualitas produk terhadap kepuasan pelanggan Café Patroli Kopi sebesar $39,6 \%$ lebih besar dari pengaruh parsial store atmosphere terhadap kepuasan pelanggan Café Patroli Kopi yaitu sebesar 25,8\% maka bisa dinyatakan bahwa kualitas produk lebih banyak memberikan kontribusi terhadap kepuasan pelanggan dibandingkan store atmosphere. Pengaruh secara simultan store atmosphere dan kualitas produk tehadap kepuasan pelanggan sebesar $65,5 \%$ sedangkan sisanya $34,5 \%$ merupakan kontribusi variabel lain yang tidak diteliti. Sedangkan berdasarkan hasil uji hipotesis dengan kriteria uji nilai sig. $(0,000)<(0,05)$ dan $f$ hitung $>f$ tabel $(248,772>3,030)$, maka keputusannya adalah Ho ditolak dan H1 diterima. Dengan demikian hal ini membuktikan bahwa Store Atmosphere (X1) dan Kualitas Produk (X2) bersama-sama berkontribusi secara simultan terhadap Kepuasan Pelanggan $(\mathrm{Y})$.
\end{abstract}

\section{Kata Kunci: Store Atmosphere; Kualitas Produk; Kepuasan Pelanggan.}

Abstract. This study aims to test and analyze the influence of Store Atmosphere and Product Quality on Customer Satisfaction at Patroli Kopi Café. Research was conducted using quantitative methods with verification analysis, namely collecting, presenting, analyzing, and testing hypotheses, and making conclusions. The sample in this study amounted to 265 using the Non Probability Sampling technique with the incidental sample method. The data analysis technique used is the data quality technique namely validity and reliability test, normality test, correlation analysis, path analysis, coefficient determination, and hypothesis test. Based on the analysis that has been conducted, the correlation coefficient between the store atmosphere variable and the product quality obtained a value of 0.744 which means that it has a significant, positive and strong level of correlation. The partial effect of product quality on customer satisfaction is $39.6 \%$ greater than the partial effect of store atmosphere on customer satisfaction, which is $25.8 \%$, it can be stated that product quality contributes more to visitor loyalty than store atmosphere. The simultaneous effect of store atmosphere and product quality on customer satisfaction is $65.5 \%$, while the remaining $34.5 \%$ is the contribution of other variables not examined. Meanwhile, based on the results of hypothesis testing with the sig value test criteria. (0.000) < (0.05) and $f$ count $>f$ table $(248.772>3.030)$, then the decision is $\mathrm{Ho}$ is rejected and $\mathrm{H} 1$ is accepted. Thus, this proves that the Store Atmosphere (X1) and Product Quality (X2) simultaneously contribute to Customer Satisfaction (Y).

Keywords: Store Atmosphere; Product Quality; Customer Satisfaction. 


\section{A. PENDAHULUAN}

Dewasa ini, dunia bisnis mengalami perkembangan yang semakin pesat. Hal tersebut diakibatkan oleh faktor-faktor yang mempengaruhi kegiatan ekonomi seperti perkembangan teknologi informasi beserta ilmu pengetahuan yang terus berkembang secara global sehingga berbagai kategori bisnis mulai bermunculan, diantaranya bisnis transportasi, bisnis properti, bisnis elektronik, bisnis kuliner, dan lain-lain. Dikutip dari Badan Ekonomi Kreatif Indonesia (Bekraf) dalam Masalembo.com (2019), industri makanan dan minuman atau bisa disebut sebagai industri kuliner berhasil menghasilkan Produk Domestik Bruto (PDB) nasional sebesar 6,34\% di tahun 2018. Pencapaian tersebut naik $0,23 \%$ dari tahun 2017 sejumlah 6,21\%.

Sementara itu, bisnis kuliner pun kian menjamur ke berbagai kota. Salah satunya adalah Kota Karawang yang memiliki pertumbuhan ekonomi dan bisnis yang cukup pesat, terlihat dari banyaknya jumlah kawasan industri, maupun bisnis kuliner yang diantaranya berupa restoran, warung, angkringan dan café. Keberadaan café di Kota Karawang semakin mudah ditemui, baik di pusat pebelanjaan maupun di pinggir jalan perkotaan. Diduga, hal ini dikarenakan semakin banyaknya masyarakat yang menjadikan café sebagai alternatif untuk menghabiskan waktu.

Salah satu café yang cukup populer dan sering dikunjungi oleh pelanggan adalah Café Patroli Kopi. Café ini berdiri sejak awal 2016 dan menggunakan konsep suasana cukup cozy dengan hiasan seperti lampu-lampu hias berwarna-warni sehingga menampilkan kesan sendu dan romantis. Berikut merupakan data penjualan Café Patroli Kopi.

Tabel 1 Data Penjualan Café Patroli Kopi Selama Tahun 2019

\begin{tabular}{|c|c|c|}
\hline No & BULAN & $\mathbf{2 0 1 9}$ \\
\hline 1 & JANUARI & 112.000 .000 \\
\hline 2 & FEBRUARI & 111.000 .000 \\
\hline 3 & MARET & 78.600 .000 \\
\hline 4 & APRIL & 113.900 .000 \\
\hline 5 & MEI & 101.000 .000 \\
\hline 6 & JUNI & 110.000 .000 \\
\hline 7 & JULI & 112.000 .000 \\
\hline 8 & AGUSTUS & 101.000 .000 \\
\hline 9 & SEPTEMBER & 90.000 .000 \\
\hline 10 & OKTOBER & 113.900 .000 \\
\hline 11 & NOVEMBER & 101.000 .000 \\
\hline 12 & DESEMBER & 99.890 .000 \\
\hline & TOTAL & $\mathbf{1 . 2 4 4 . 2 9 0 . 0 0 0}$ \\
\hline
\end{tabular}

Sumber : Survei Peneliti, 2020 
Namun, terjadi penurunan penjualan di Café Patroli Kopi selama tahun 2019. Apabila fenomena tersebut dibiarkan ditengah-tengah persaingan usaha café yang semakin ketat, maka dikhawatirkan setiap bulan akan terjadi penurunan penjualan. Hal tersebut diduga karena menurunnya tingkat kepuasan pelanggan Patroli Kopi.

Untuk dapat menarik konsumen dalam jumlah besar, perusahaan selalu melakukannya dengan menunjukkan keunggulan produk yang dimiliki dan memuaskan pelanggannya (Priyono, 2017). Sabir et al. dalam Miswanto \& Angelia (2017) berpendapat bahwa kepuasan muncul dari persepsi dan harapan pelanggan. Kepuasan pelanggan akan terpenuhi saat perusahaan memberikan produk atau jasa yang sepadan dengan apa yang dirasakan oleh pelanggan. Upaya - upaya dalam memenuhi kebutuhan pelanggan tersebut merupakan cara untuk meningkatkan kepuasan pelanggan (Khairusy \& Febriani, 2020).

Suasana yang nyaman didukung desain interior yang menarik dan beragam fasilitas yang disediakan diduga berpengaruh positif pada kepuasan pelanggan saat mengunjungi café. Store atmosphere sendiri meliputi kombinasi karakteristik fisik berupa tata letak, arsitektur, warna, pencahayaan, suhu, musik, aroma, dan lain-lain dan ditujukan untuk membentuk suatu citra positif di benak konsumen (Pratminingsih et al., 2018).

Selain store atmosphere, faktor lain yang tidak kalah utama bagi konsumen dalam memilih tempat makan adalah kualitas produk yang disajikan oleh tempat makan itu sendiri. Kualitas produk menjelaskan karakteristik dari produk tersebut dalam mencukupi serta memenuhi kebutuhan konsumen (Kotler \& Armstrong, 2012:273). Agar bisa bertahan dalam persaingan usaha yang semakin kompetitif, para pelaku bisnis café dituntut untuk mempu menciptakan keunggulan tersendiri atas kualitas produk yang disajikan dan suasana (atmosphere) café dalam upaya memuaskan pelanggan.

Berdasarkan uraian dan latar belakang permasalahan yang ada dan disebutkan diatas, peneliti mengambil tema untuk penelitian ini dengan judul "Store Atmosphere dan Kualitas Produk Berpengaruh Pada Proses Kepuasan Pelanggan (Survey Pada Café Patroli Kopi Karawang)".

Dari uraian tersebut, dapat diketahui rumusan masalah dalam penelitian ini, diantaranya (1) Seberapa besar korelasi antara store atmosphere dan kualitas produk pada Café Patroli Kopi Karawang?; (2) Seberapa besar pengaruh secara parsial antara store atmosphere dan kualitas produk terhadap kepuasan pelanggan Café Patroli Kopi Karawang?; serta (3) Seberapa besar pengaruh secara simultan antara store atmosphere dan kualitas produk terhadap kepuasan pelanggan Café Patroli Kopi Karawang?

Daril rumusan masalah di latas, dapat diketahui tujuan dilakukannya penelitian ini, diantaranya (1) Untuk mengukur dan menganalisis seberapa besar korelasi antara store atmosphere dan kualitas produk pada Café Patroli Kopi Karawang; (2) Untuk mengukur dan menganalisis seberapa besar pengaruh parsial antara store atmosphere dan kualitas produk terhadap kepuasanl pelanggan Cafél Patroli Kopi Karawang; (3) Untuk mengukur dan menganalisis seberapa besar pengaruh simultan antara store atmosphere dan kualitas produk terhadap kepuasan pelanggan Café Patroli Kopi Karawang. 


\section{B. KAJIAN LITERATUR}

\section{Pengertian Store Atmosphere}

Francioni et al. (2018) menyatakan, store atmosphere secara umum diartikan sebangai seluruh elemen fisik dan nonfisik dari perusahaan yang dapat berdampak pada sikap pelanggan terhadap perusahaan.

Menurut Berman et al. (2018:465), dimensi store atmosphere meliputi beberapa elemen, yaitu :

1. Exterior (Bagian Luar Toko), yang memiliki pengaruh cukup kuat terhadap citra toko patut dirancang sebaik mungkin agar dapat menarik perhatian pelanggan.

2. General Interior (Bagian Dalam Toko), yaitu bagian yang harus didesain dengan baik guna menonjolkan visual merchandising semaksimal mungkin. Display dibuat agar bisa menarik perhatian pelanggan dan membuat mereka memperhatikan, memeriksa serta memilih produk dan melakukanl pembelian.

3. Store Layout (tata letak toko), yaitu sebuah rencana dalam menentukan lokasi dan fasilitas tertentu di dalam toko sehingga memudahkan pelanggan untuk berlalu lalang didalamnya. Saat pelanggan melihat ruangan dalam toko melalui etalase atau pintu masuk, store layout akan memancing mereka masuk ke dalam toko serta memberikan kenyamanan bagi para pelanggan yang berlalu lalang.

4. Interior Display (tampilan bagian dalam toko), yang bertujuan untuk memberi informasi pada pelanggan, meningkatkan suasana toko, dan memberikan promosi yang menarik pelanggan.

\section{Pengertian Kualitas Produk}

Kualitas produk meliputi karakteristik dari suatu produk ataupun jasa yang terikat pada fungsinya dalam memenuhi kebutuhan pelanggan yang dapat dinyatakan dan dapat dirasakan oleh pelanggan tersebut (Kotler \& Armstrong, 2012:230).

Kotler \& Armstrong (2012:230) mengemukakan bahwa terdapat dimensi-dimensi kualitas yang dipakai sebagai kerangka perencanaan analisis dan strategis, yaitu : (1) Kinerja (performance); (2) Keistimewaan atau ciri-ciri (features); (3) Kehandalan (reability); (4) Kesesuaian dengan spesifikasi (comformance to specification); (5) Daya tahan (durability); (5) Keindahan (aestetics); dan (6) Kualitas yang dipersepsikan (perceived quality).

Sementara itu Potter \& Hotchkiss (2012:65) mengemukakan bahwa pada intinya elemenelemen yang mempengaruhi kualitas produk yang khusus mengukur kualitas makanan, yaitu : (1) Warna; (2) Penampilan; (3) Porsi; (4) Bentuk; (5) Tekstur; (6) Aroma; dan (7) Rasa.

Pengertian Kepuasan Pelanggan

Kepuasan pelanggan merupakan suatu respons pelanggan terhadap perbedaan diantara ekspektasi yang diharapkan (standar tertentu) dan kemampuan produk secara nyata yang dipersepsikan setelah mengonsumsi produk ataupun jasa tersebut (Tjiptono \& Diana, 2019:117). 
Menurut Tjiptono dalam Aldianto (2018), kepuasan pelanggan memiliki beberapa indikator, diantaranya : (1) Kesesuaian harapan, merupakan kesuaian antara harapan yang diinginkan dan dirasakan oleh konsumen dengan kinerja produk/jasa yang didapat; (2) Minat berkunjung kembali, yaitu konsumen yang sukarela kembali berkunjung dengan senang hati serta membeli ulang produk/jasa tertentu; dan (3) Kesediaan merekomendasikan, yaitu konsumen yang sukarela merekomendasikan produk/jasa serta memberitahukan kelebihan yang mereka dapatkan kepada kerabat ataupun teman.

\section{Kerangka Pemikiran}

Menurut Sugiyono (2019:95), suatu pola yang menjelaskan tentang teori bermacammacam faktor yang sudah diidentifikasikan sebagai masalah penelitian disebut sebagai kerangka pemikiran. Kerangka pemikiran menggambarkan hubungan daril variabel independent Store Atmosphere (X1) dan Kualitas Produk (X2) terhadap variabel dependent Kepuasan Pelanggan (Y).

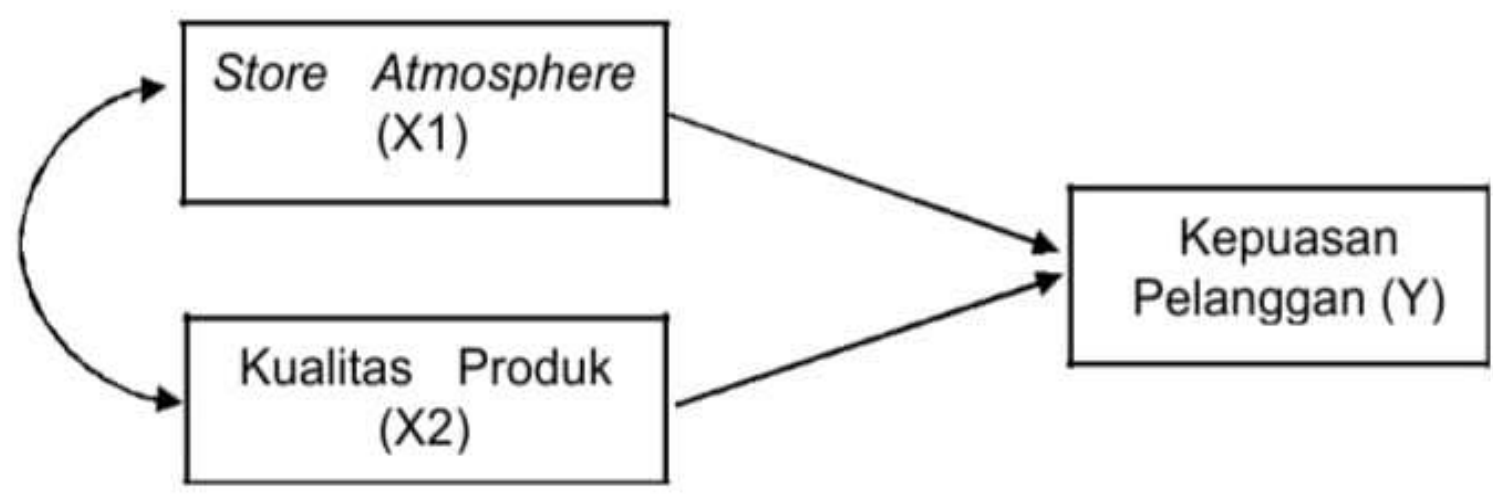

\section{Gambar 1 Kerangka Pemikiran}

Hipotesis Penelitian

Daril teori-teori yangl dikemukakan olehl para ahlil serta kajian penelitianl yang penulis dapatkan, terdapat beberapa hipotesis yang akan penulis kemukakan, diantaranya : H1 : Terdapat korelasi antara Store Atmosphere dan Kualitas Produk (Survey pada Cafe Patroli Kopi Karawang).

H2 : Terdapat pengaruh parsial antara Storel Atmosphere dan Kualitas Produk terhadap Kepuasan Pelanggan (Survey pada Cafe Patroli Kopi Karawang).

H3 : Terdapat pengaruh simultan antara Store Atmosphere dan Kualitas Produk terhadap Kepuasan Pelanggan (Survey padal Cafe Patroli Kopi Karawang).

\section{METODOLOGI PENELITIAN}

Dalam penelitian ini, penulis memakai metode deskriptif verifikatif, yaitu merupakan metode penelitian kuantitatif yang dipakai dalam meneliti populasi ataupun sampel tertentu, serta menguji dan menganalisis hipotesis yang sudah dikemukakan dengan cara analisis data yang bersifat statistik (Sugiyono, 2019:13). Populasinya adalah seluruh pelanggan Patroli Kopi Karawang. Dengan jumlah pengunjung yang ditargetkan dari bulan Januari hingga Desember 2019, yaitu sebanyak 13.825 orang. Dengan memakai rumus Isaac \& Michael dengan taraf kesalahan 10\% didapatkan sampel sebanyak 265 orang. Teknik 
sampling yang dipakai dalam penelitian ini adalah sampling insidental yang termasuk dalam nonprobability sampling. Sedangkan teknik pengambilan datanya dengan melakukan wawancara, kuisoner, dan observasi. Serta teknik analisis data yang dipakai yaitu teknik analisis skala likert, analisis korelasi, analisis jalur dan koefisien determinasi

\section{HASIL DAN EMBAHASAN}

\section{a. Uji Validitas}

Tabel 2 Hasil Uji Validitas Variabel Store Atmosphere (X1)

\begin{tabular}{|c|l|l|r|c|}
\hline No & \multicolumn{1}{|c|}{ Indikator } & r hitung & \multicolumn{1}{c|}{$\mathbf{r}$ tabel } & Keterangan \\
\hline 1 & Bagian Depan Cafe & 0,589 & 0,300 & Valid \\
\hline 2 & Papan Nama & 0,376 & 0,300 & Valid \\
\hline 3 & Pintu Masuk & 0,588 & 0,300 & Valid \\
\hline 4 & Fasilitas Tempat Parkir & 0,484 & 0,300 & Valid \\
\hline 5 & Warna dan Pencahayaan & 0,622 & 0,300 & Valid \\
\hline 6 & Aroma dan Musik & 0,697 & 0,300 & Valid \\
\hline 7 & Suhu & 0,616 & 0,300 & Valid \\
\hline 8 & Pramusaji & 0,700 & 0,300 & Valid \\
\hline 9 & Kebersihan & 0,717 & 0,300 & Valid \\
\hline 10 & Penataan Barang & 0,637 & 0,300 & Valid \\
\hline 11 & Pengaturan Antar Meja & 0,693 & 0,300 & Valid \\
\hline 12 & Penyajian Produk dalam Menu & 0,601 & 0,300 & Valid \\
\hline 13 & Dekorasi Dinding & 0,669 & 0,300 & Valid \\
\hline
\end{tabular}

Sumber : Hasil Pengolahan Data SPSS, diolah peneliti 2020

Dari pengolahan SPSS yang dilakukan, bisa dilihat bahwa hasil uji validitas variabel Store Atmosphere (X1) sebanyak 13 indikator memiliki nilai $r$ hitung $>0,300$ sehingga pernyataan kuisioner dinyatakan valid.

Tabel 3 Hasil Uji Validitas Variabel Kualitas Produk (X2)

\begin{tabular}{|c|l|l|r|c|}
\hline No & \multicolumn{1}{|c|}{ Indikator } & r hitung & r tabel & Ket \\
\hline 1 & Kombinasi warna makanan & 0,674 & 0,300 & Valid \\
\hline 2 & Kombinasi warna minuman & 0,641 & 0,300 & Valid \\
\hline 3 & Tampilan makanan & 0,579 & 0,300 & Valid \\
\hline 4 & Tampilan minuman & 0,645 & 0,300 & Valid \\
\hline 5 & Porsi makanan & 0,569 & 0,300 & Valid \\
\hline 6 & Porsi minuman & 0,661 & 0,300 & Valid \\
\hline 7 & Aroma makanan & 0,732 & 0,300 & Valid \\
\hline 8 & Rasa makanan & 0,677 & 0,300 & Valid \\
\hline 9 & Rasa minuman & 0,710 & 0,300 & Valid \\
\hline 10 & Kebersihan makanan dan minuman & 0,723 & 0,300 & Valid \\
\hline 11 & Pelayanan pramusaji & 0,647 & 0,300 & Valid \\
\hline 12 & Waktu tunggu pesanan & 0,541 & 0,300 & Valid \\
\hline 13 & Makanan/Minuman disajikan sesuai dengan menu & & & \\
\hline
\end{tabular}

Sumber : Hasil Pengolahan Data SPSS, diolah peneliti 2020 
Dari pengolahan SPSS yang dilakukan, bisa dilihat bahwa hasil uji validitas variabel Kualitas Produk (X2) sebanyak 13 indikator memiliki nilai $r$ hitung $>0,300$ sehingga pernyataan kuisioner dinyatakan valid.

Tabel 4 Hasil Uji Validitas Variabel Kepuasan Pelanggan $(Y)$

\begin{tabular}{|c|c|c|c|c|}
\hline No & Indikator & r hitung & $r$ tabel & Keterangan \\
\hline 1 & $\begin{array}{l}\text { Produk yang disajikan sesuai } \\
\text { harapan }\end{array}$ & 0,694 & 0,300 & Valid \\
\hline 2 & Suasana café sesuai harapan & 0,783 & 0,300 & Valid \\
\hline 3 & Fasilitas café sesuai harapan & 0,765 & 0,300 & Valid \\
\hline 4 & $\begin{array}{lcc}\text { Minat } \quad \text { berkunjung } & \text { kembali } \\
\text { karena suasana café } & \end{array}$ & 0,792 & 0,300 & Valid \\
\hline 5 & $\begin{array}{lr}\text { Minat berkunjung } & \text { kembali } \\
\text { karena fasilitas café } & \end{array}$ & 0,730 & 0,300 & Valid \\
\hline 6 & $\begin{array}{l}\text { Minat berkunjung kembali } \\
\text { karena produk yang disajikan }\end{array}$ & 0,728 & 0,300 & Valid \\
\hline 7 & $\begin{array}{l}\text { Niat rekomendasi karena } \\
\text { suasana café }\end{array}$ & 0,825 & 0,300 & Valid \\
\hline 8 & $\begin{array}{l}\text { Niat rekomendasi } \\
\text { fasilitas cafe }\end{array}$ & 0,736 & 0,300 & Valid \\
\hline 9 & $\begin{array}{l}\text { Niat } \quad \text { rekomendasi } \\
\text { produk yang disajikan }\end{array}$ & 0,748 & 0,300 & Valid \\
\hline
\end{tabular}

Sumber : Hasil Pengolahan Data SPSS, diolah peneliti 2020

Dari pengolahan SPSS yang dilakukan, bisa dilihat bahwa hasil uji validitas variabel Kepuasan Pelanggan $(Y)$ sebanyak 9 indikator memiliki nilai $r$ hitung $>0,300$ sehingga pernyataan kuisioner dinyatakan valid.

\section{b. Uji Reliabilitas}

Dalam teknik pengujian reliabilitas memakai keabsahan alpha Cronbach dengan taraf kesalahan 5\%. Dilakukan dengan membandingkan hasil alpha Cronbach yang telah dihitung dengan angka tabel $r$ hitung sehingga menentukan reliabel atau tidaknya instrumen. Apabila $(\alpha)>0,600$ maka reliabilitasnya pernyataan dapat diterima. Hasil uji reliabilitas variabel Storel Atmosphere (X1), Kualitas Produk (X2), dan Kepuasan Pelanggan $(\mathrm{Y})$ bisa dilihat pada tabel 5 sebagai berikut :

Tabel 5 Hasil Uji Reliabilitas

\begin{tabular}{|l|r|r|l|}
\hline \multicolumn{1}{|c|}{ Variabel } & r hitung & r kritis & Kriteria \\
\hline Store Atmosphere & 0,859 & 0,600 & Reliabel \\
\hline Kualitas Produk & 0,887 & 0,600 & Reliabel \\
\hline Kepuasan Pelanggan & 0,906 & 0,600 & Reliabel \\
\hline
\end{tabular}

Sumber : Hasil Pengolahan Data SPSS, diolah peneliti 2020 
Dari pengolahan SPSS yang dilakukan, bisa dilihat jika hasil uji reliabilitas diketahui bahwa untuk setiap variabel Store Atmosphere (X1), Kualitas Produk (X2), dan Kepuasan Pelanggan $(Y)$, nilai alpha Cronbach $(\alpha)>0,600$, sehingga variabel Store Atmosphere $(X 1)$, Kualitas Produk (X2), dan Kepuasan Pelanggan (Y) dinyatakan reliabel.

\section{c. Uji Normalitas Data}

Dalam penelitian ini, metode Kolmogorov-Smirnov yang dipakai sebagai uji normalitas untuk mengetahui apakah data tersebut mengikuti sebaran normal ataupun tidak. Ketentuannya apabila nilai $\alpha$ hitung daril variabel tersebut lebih besar dari 0,05 , berarti variabel tersebut mengikuti distribusi normal. Dari pengujian SPSS yang dilakukan, hasil dari uji normalitas variabel Store Atmosphere (X1), Kualitas Produk (X2), dan Kepuasan Pelanggan ( $\mathrm{Y}$ ) ada dalam tabel berikut :

Tabel 6 Hasil Uji Normalitas

\begin{tabular}{|l|l|r|}
\hline \multicolumn{2}{|c|}{ One-Sample Kolmogorov-Smirnov Test } \\
\hline & & $\begin{array}{r}\text { Unstandardiz } \\
\text { ed Residual }\end{array}$ \\
\hline $\mathrm{N}$ & 265 \\
\hline \multirow{2}{*}{ Normal Parameters ${ }^{\mathrm{a}}$} & Mean & .0000000 \\
\cline { 2 - 3 } & Std. Deviation & .46787880 \\
\hline $\begin{array}{l}\text { Most Extreme } \\
\text { Differences Absolute }\end{array}$ & .071 \\
\cline { 2 - 3 } & Positive & .071 \\
\cline { 2 - 3 } & Negative & -.040 \\
\hline Kolmogorov-Smirnov Z & 1.152 \\
\hline Asymp. Sig. (2-tailed) & .140 \\
\hline
\end{tabular}

Sumber : Hasil Pengolahan Data SPSS, diolah peneliti 2020

Dari pengolahan SPSS yang dilakukan, menunjukan bahwa semual variabel mengikutil penyebaran data normal yaitu dengan nilai 0,140 , dikarenakan nilai signifikan $r$ hitung variabel lebih dari 0,05 . Artinya variabel bebas dan terikat mengikuti sebaran data normal.

\section{d. Analisis Korelasi}

Tabel 7Hasil Korelasi Variabel Store Atmosphere (X1) dan Kualitas Produk (X2)

\begin{tabular}{|l|l|r|r|}
\hline \multicolumn{3}{|c|}{ Correlations } \\
\hline \multirow{2}{*}{ Store Atmosphere } & $\begin{array}{c}\text { Store } \\
\text { Atmosphere }\end{array}$ & $\begin{array}{c}\text { Kualitas } \\
\text { Produk }\end{array}$ \\
\cline { 2 - 4 } & Pearson Correlation & 1 &, 744 \\
\cline { 2 - 4 } & Sig. (2-tailed) & 265 &, 000 \\
\cline { 2 - 4 } & $\mathrm{N}$ &, 744 & 265 \\
\hline \multirow{3}{*}{ Kualitas Produk } & Pearson Correlation &, 000 & 1 \\
\cline { 2 - 4 } & Sig. (2-tailed) & 265 & 265 \\
\cline { 2 - 4 } & $\mathrm{N}$ & & \\
\hline$* *$ Correlation is significant at the 0.01 level (2-tailed). & \\
\hline
\end{tabular}

Sumber : Hasil Pengolahan Data, diolah peneliti 2020 
Dari pengolahan SPSS yang dilakukan, hasil analisis korelasi kedua variabel tersebut di peroleh korelasi sebesar 0,744. Sehingga dapat disimpulkan hubungan Store Atmosphere (X1) dan Kualitas Produk (X2) saling berkorelasi dan mempunyai hubungan yang kuat, sesuai dengan tabel di bawah ini

\section{e. Analisis Jalur}

Tabel 8 Hasil Analisis Jalur

\begin{tabular}{|c|c|c|c|c|c|c|}
\hline \multirow{2}{*}{\multicolumn{2}{|c|}{ Model }} & \multicolumn{2}{|c|}{ Unstandardized Coefficients } & $\begin{array}{l}\text { Standardized } \\
\text { Coefficients }\end{array}$ & \multirow[b]{2}{*}{$\mathrm{t}$} & \multirow[b]{2}{*}{ Sig. } \\
\hline & & $B$ & Std. Error & Beta & & \\
\hline 1 & (Constant) & $-2,688$ & 1,754 & & \begin{tabular}{|l|l|}
$-1,533$ \\
\end{tabular} & ,127 \\
\hline & Store Atmosphere & ,295 &, 045 & ,352 & 6,487 &, 000 \\
\hline & Kualitas Produk & ,427 & ,045 & ,512 & 9,426 & ,000 \\
\hline
\end{tabular}

Pengaruh Parsial Store Atmosphere terhadap Kepuasan Pelanggan

Dari pengolahan SPSS yang dilakukan tabel di atas, koefisien jalur variabel Store Atmosphere $(X 1)$ terhadap Kepuasanl Pelanggan $(Y) I$ yaitu sebesar 0,352. Sehingga didapatkan nilai persamaan $\mathbf{Y}=0,352 \mathbf{X 1}$.

Pengaruh Parsial Kualitas Produk terhadap Kepuasan Pelanggan

Dari pengolahan SPSS yang dilakukan, koefisien jalur untuk variabel Kualitas Produk (X2) terhadap Kepuasal Pelanggan (Y)I yaitu sebesar 0,512. Jadi didapatkan persamaan $\mathrm{Y}=0,512(\mathrm{X} 2)$.

Tabel 9 Pengaruh Store Atmosphere dan Kualitas Produk terhadap Kepuasan Pelanggan

\begin{tabular}{|c|c|c|c|c|c|}
\hline \multirow{2}{*}{ Variabel } & \multirow{2}{*}{$\begin{array}{c}\text { Koefisien } \\
\text { Jalur }\end{array}$} & \multirow{2}{*}{$\begin{array}{l}\text { Pengaruh } \\
\text { Langsung }\end{array}$} & \multicolumn{2}{|c|}{ Pengaruh Tidak Langsung } & \multirow{2}{*}{$\begin{array}{l}\text { Sub Total } \\
\text { Pengaruh }\end{array}$} \\
\hline & & & $\mathbf{X}_{1}$ & $\mathbf{X}_{2}$ & \\
\hline $\begin{array}{c}\text { Store } \\
\text { Atmosphere }\end{array}$ & 0,352 & $\begin{array}{c}0,352^{2}= \\
0,124\end{array}$ & - & $\begin{array}{c}(0,352 \times 0,512 \times \\
0,744)=0,134\end{array}$ & 0,258 \\
\hline $\begin{array}{l}\text { Kualitas } \\
\text { Produk }\end{array}$ & 0,512 & $\begin{array}{c}0,512^{2}= \\
0,262\end{array}$ & $\begin{array}{r}(0,352 \times 0,512 \times \\
0,744)=0,134\end{array}$ & - & 0,396 \\
\hline \multicolumn{5}{|c|}{ Total Pengaruh } & 0,655 \\
\hline \multicolumn{5}{|c|}{ Pengaruh Variabel Lain } & 0,345 \\
\hline
\end{tabular}

Sumber : Hasil Pengolahan Data, diolah peneliti 2020

Dari pengolahan data yang dilakukan, dapat dilihat jika pengaruh simultan Store Atmosphere dan Kualitas Produk terhadap Kepuasan Pelanggan yakni 0,655 atau sebesar $65,5 \%$. Sedangkan pengaruh variabel lain dari luar model adalah 0,345 atau $34,5 \%$. 


\section{f. Uji Koefisien Determinasi}

Tabel 10 Koefisien Determinasi

\begin{tabular}{|c|c|c|c|c|}
\hline Model & $\mathrm{R}$ & $\mathrm{R}$ Square & $\begin{array}{c}\text { Adjusted } \mathrm{R} \\
\text { Square }\end{array}$ & Std. Error of the Estimate \\
\hline 1 & $.809^{\mathrm{a}}$ & .655 & .652 & 3.61705 \\
\hline
\end{tabular}

a. Predictors: : (Constant), Kualitas Produk, Store Atmosphere

b. Dependent Variable: Kepuasan Pelanggan

Sumber : Hasil Pengolahan Data SPSS, diolah peneliti 2020

Daril hasil pengolahan SPSS yang dilakukan menunjukkan bahwa koefisien determinasi sejumlah 0,655 yang berarti 65,5\%. Artinya bahwa Kepuasan Pelanggan Café Patroli Kopi dipengaruhi oleh Store Atmosphere dan Kualitas Produk, sementara sisanya sejumlah $34,5 \%$ merupakan variabel lain yang kontribusinya tidak diteliti.

\section{g. Uji Hipotesis}

Untuk pengaruh simultan Store Atmosphere dan Kualitas Produk terhadap Kepuasan Pelanggan dengan tingkat signifikan $(\alpha)=5 \%$ dan derajat kebebasan $1(\mathrm{dk} 1)=$ 2 dan derajat kebebasan $2(\mathrm{dk} 2)=\mathrm{n}-2-1=265-2-1=262$, maka berdasarkan tabel distribusikan-f didapat nilai $f_{\text {tabel }}$ sebesar 3,030 . Sedangkan $f_{\text {hitung }}$ bisa dilihat dan dihitung dari tabel di bawah ini.

Tabel 11 Hasil Perhitungan Nilai $f$

ANOVA $^{a}$

\begin{tabular}{|ll|r|r|r|r|r|}
\hline \multicolumn{2}{|l|}{ Model } & \multicolumn{1}{c|}{$\begin{array}{c}\text { Sum of } \\
\text { Squares }\end{array}$} & df & Mean Square & F & Sig. \\
\hline 1 & Regression & 6509,418 & 2 & 3254,709 & 248,772 &, $000^{\mathrm{b}}$ \\
& Residual & 3427,766 & 262 & 13,083 & & \\
& Total & 9937,184 & 264 & & & \\
\hline
\end{tabular}

a. Dependent Variable: Kepuasan Pelanggan

b. Predictors: (Constant), Kualitas Produk, Store Atmosphere

\section{Sumber : Hasil Pengolahan Data SPSS, diolah peneliti 2020}

Dari pengolahan data yang dilakukan, dapat di jelaskan jika nilail sig. $(0,000) \mathrm{l}<(0,05)$ dan fhitung $>$ ftabel $(248,772>3,030)$. Artinya $\mathrm{HO}$ ditolak dan $\mathrm{H} 1$ diterima, Bisa disimpulkan Store Atmosphere dan Kualitas Produk secara simultan berpengaruh signifikan terhadap Kepuasan Pelanggan. 


\section{E. KESIMPULAN}

Dari hasil penelitian serta pembahasan hasil analisis mengenai Pengaruh Store Atmosphere dan Kualitas Produk terhadap Kepuasan Pelanggan di Cafe Patroli Kopi, terdapat hal-hal yang dapat dijadikan kesimpulan hasil penelitian yaitu:

1. Besaran Korelasi antara variabel bebas yaitu Store Atmosphere dan Kualitas produk menunjukkan korelasi sebesar 0,744 sehingga kedua variabel tersebut mempunyai hubungan yang positif, kuat dan signifikan.

2. Besaran pengaruh parsial Kualitas Produk terhadap Kepuasan Pelanggan di Cafe Patroli Kopi memiliki pengaruh lebih besar sebesar 0,396 atau 39,6\%, sedangkan Store Atmosphere terhadap Kepuasan Pelanggan di Cafe Patroli Kopi memiliki pengaruh yang lebih kecil dengan pengaruh sebesar 0,258 atau 25,8\%.

3. Besaran pengaruh secara simultan Store Atmosphere dan Kualitas Produk berpengaruh terhadap Kepuasan Pelanggan secara simultan dengan pengaruh sebesar 0,655 atau $65,5 \%$, sementara sisanya sebesar 0,345 atau $34,5 \%$ dipengaruhi oleh variabel lain yang tidak diteliti. Sedangkan hasil perhitungan nilai $f$ dengan kriteria uji nilai sig. $I(0,000)<(0,05)$ dan f hitung $>$ f tabel $(248,772>3,030)$, maka keputusannya adalah Ho ditolak dan $\mathrm{H} 1$ diterima. Hal ini membuktikan bahwa Store Atmosphere (X1) dan Kualitas Produk (X2) secara bersama-sama berkontribusi secara simultan terhadap Kepuasan Pelanggan (Y).

Store atmosphere dan kualitas produk secara bersama-sama memiliki pengaruh terhadap kepuasan pelanggan, maka dari itu untuk meningkatkan rasa kepuasan pelanggan diharapkan cafe patroli kopi memperhatikan store atmosphere dan kualitas produk yang disajikan kepada pelanggan. Yaitu dengan memberikan suatu hal yang baru dan unik dalam produknya, serta adanya peningkatan fasilitas dan atribut cafe patroli kopi itu sendiri maupun kualitas produknya, sehingga pelanggan bisa merasakan suasana yang nyaman dan makanan yang berkualitas saat berkunjung ke café patroli kopi.

\section{DAFTAR PUSTAKA}

Aldianto, R. (2018). Analisis Pengaruh Kualitas Pelayanan, Harga dan Atmosphere Toko Terhadap Loyalitas Pelanggan Melalui Kepuasan Pelanggan. Universitas Lampung.

Barbara Francioni, Elisabetta Savellia , Marco Cioppi (2018). Store satisfaction and store loyalty: The moderating role of store atmosphere. Journal of Retailing and Consumer Services 43, 333-341.

Berman, B., Evans, J. R., \& Chatterjee, P. (2018). RETAIL MANAGEMENT (Thirteenth). Pearson Education.

Departemen Pendidikan Indonesia. (2016). Kamus Besar Bahasa Indonesia. Jakarta : Balai Pustaka

Khairusy, M. A., \& Febriani, R. (2020). Pengaruh Kualitas Produk dan Kualitas Pelayanan Terhadap Kepuasan Pelanggan (Survey pada Pelanggan KFC Store Merdeka Bandung). Jurnal Manajemen Dan Bisnis FEB UNBAJA, 1-12. https://doi.org/2686$\underline{0554}$

Kotler, P., \& Armstrong, G. (2012). Principles of Marketing. 14e. In Prentice Hall (Issue 
14e). Pearson Education. https://doi.org/10.2307/2548367

Kusumawathi, N. W. G., Darmawan, D. P., \& Suryawardani, I. G. . O. (2019). Pengaruh Store Atmosphere, Kualitas Produk, dan Kualitas Layanan terhadap Kepuasan Konsumen di Seniman Coffee Studio. E-Jurnal Agribisnis Dan Agrowisata, 8(1), 1-10. https://doi.org/2301-65

Lesmana, R., Sunardi, N., Hastono, H., \& Widodo, A. S. (2021). Perceived Quality Membentuk Customer Loyalty via Brand Equity pada Pengguna Smartphone Merek Xiaomi di Tangerang Selatan. Jurnal Pemasaran Kompetitif, 4(2), 157-167.

Lesmana, R., Widodo, A. S., \& Sunardi, N. (2020). The Formation of Customer Loyalty From Brand Awareness and Perceived Quality through Brand Equity of Xiaomi Smartphone Users in South Tangerang. Jurnal Pemasaran Kompetitif, 4(1), 1-12.

Levy, M., \& Weitz, B. A. (2012). Retailing Management (Eight Edit). McGraw-Hill.

Miswanto, \& Angelia, Y. R. (2017). The Influence of Service Quality and Store Atmosphere on Customer Satisfaction. JMK, 19(2), 106-111. https://doi.org/10.9744/jmk.19.2.106

Potter, N. N., \& Hotchkiss, J. H. (2012). Food Science (fifth Edit). Chapman and Hall.

Pratminingsih, S. A., Haizam, M., Saudi, M., Surayya, N., \& Saudi, M. (2018). Store Atmosphere and Food quality as Determinant Factors in Visiting Traditional Restaurant in Bandung, Indonesia. 7, 287-290.

Priyono, I. (2017). Effect of Quality Products, Services and Brand on Customer Satisfaction at McDonald 's. 5(2), 2-5. https://doi.org/10.4172/2375-4389.1000247

Rahman, S. (2019). Menyoal Kontribusi Industri Kuliner sebagai Subsektor Ekonomi Kreatif. Masalembo.Com. htps://www.masalembo.com/2019/menyoal-kontribusikuliner.html?m

Sugiyono. (2019). Metode Penelitian Kuantitatif, Kualitatif dan $R \& D$ (Edisi Kedua). Alfabeta.

Sunardi, N., \& Lesmana, R. (2020). Konsep Icepower (Wiramadu) sebagai Solusi Wirausaha menuju Desa Sejahtra Mandiri (DMS) pada Masa Pandemi Covid-19. JIMF (Jurnal IImiah Manajemen Forkamma), 4(1).

Tjiptono, F., \& Diana, A. (2019). Kepuasan Pelanggan: Konsep, Pengukuran \& Strategi. Penerbit Andi. 